\title{
Geophysical and Geomorphological Analysis of the Teton Fault, Wyoming
}

\section{Authors}

Mark Zellman, Glenn Thackray, Amie Staley, Harrison Colandrea, Nick Patton, and Dan O'Connell 


\title{
GEOPHYSICAL AND GEOMORPHOLOGICAL ANALYSIS OF THE TETON FAULT, WYOMING
}

\author{
MARK ZELLMAN $\uparrow$ FUGRO CONSULTANTS, INC. $\uparrow$ DENVER, CO \\ GLENN THACKRAY $\uparrow$ AMIE STALEY $\downarrow$ HARRISON COLANDREA $\uparrow$ NICK PATTON \\ IDAho STATE UNIVERSITY $\uparrow$ POCATEllo, ID

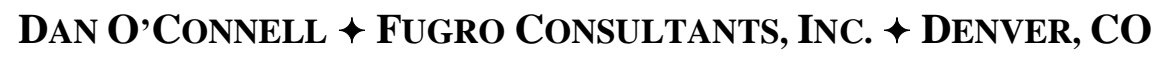

\section{$\uparrow \quad$ SUMMARY}

This investigation applied geophysical and geomorphological analyses of the Teton Fault to assess its geometry, history, and influences on landscape evolution. This project builds on results from a preceding geophysical study completed one year ago (Thackray et al. 2014), a recent study of fault scarp morphology (Thackray and Staley, in review), and years of previous studies of the fault by many practitioners.

The Teton fault, a down-to-the east normal fault, is expressed as a distinct topographic escarpment along the base of the eastern front of the Teton Range in Wyoming. The fault scarp cuts into deglacial surfaces in several similar valleys; taking the average scarp height and assuming deglaciation 15,000 yr BP indicates an average postglacial offset rate of 0.87 $\mathrm{m} / \mathrm{ka}$ (Thackray and Staley, in review). Because the fault is located almost entirely within the Great Teton National Park (GTNP) boundary, in remote and difficult terrain, very few subsurface evaluations of this fault have occurred. As a result, many uncertainties exist in the present fault characterization, including along-strike slip rate, down-dip geometry, and rupture history, among other parameters. Additionally, questions remain about the fault dip at depth.
The geomorphological component of this study focused on refinement of surficial geological mapping and fault scarp height measurements. Geomorphic mapping was accomplished using two existing LiDAR datasets: one collected by EarthScope (2008) and the other more recently by GTNP (2014). Bare-Earth data were processed to produce hillshade and slope angle maps, and DEMs were used to update previous fault-zone geomorphologic mapping and to measure vertical offset across the fault scarp (Thackray and Staley, in review). Samples were collected for cosmogenic radionuclide surface exposure dating on a high lateral moraine north of Taggart Lake, and on the deglacial surface cut by the fault scarp upvalley of Taggart Lake. We also examined soils and sediments in an extensive marsh at the upvalley end of Taggart Lake.

The geophysical component of this investigation included new, non-invasive 2D seismic surveys: P-wave (Vp) refraction and Interferometric Multi-Channel Analysis of Surface Waves (IMASW) (O'Connell and Turner 2011) depth-averaged shear wave velocity (Vs) at Taggart Lake and a site in Granite Creek near the Byrd (1995) trench location. This study also included the reprocessing of data collected at Taggart Lake in the previous study and reevaluation of the interpreted results (Thackray et al., 2014). The shallow seismic surveys use a non-invasive portable data collection system to image the Teton fault zone, in an effort to provide a basis for estimating vertical offsets of buried faulted bedrock and alluvium. 
The findings of this investigation show that surficial topographic scarp heights measured from GTNP (2014) LiDAR and buried velocity horizons imaged in Vp profiles at Taggart Lake and Granite Creek show similar offsets of $\sim 12-13 \mathrm{~m}$ for post glacial deposits and surfaces. At Taggart Lake the approximate alluvial/bedrock contact was mapped from IMASW surveys, providing a basis for estimating the dip of the Teton fault dip (perhaps no less than $70^{\circ}$ ) in the upper $200 \mathrm{~m}$. However, a high degree of uncertainty is associated with the top of rock depth picks due to their significant depth relative to the seismic survey length.

\section{$\uparrow \quad$ STUdy AREA}

This study evaluated two sites on the Teton fault within GTNP using shallow seismic survey methods (Figure 1). At the Taggart Lake and Granite Creek sites, 2D Vp refraction tomography and IMASW Vs data were collected across and parallel to the Teton fault scarp, respectively, to evaluate vertical offset and image the fault structure in the shallow subsurface. These sites were selected based upon several selection criteria: 1) on the main trace of the Teton fault, 2) simple fault geometry where all or most slip appears to be accommodated on a single strand, 3) sparse or open vegetation cover, 4) within hiking distance from the nearest trailhead, and 5) expectation of velocity contrasts created by slower alluvium in the hanging wall directly juxtaposing crystalline bedrock of the footwall, improving chances of successful imaging with seismic methods. Additionally, the Granite Creek site was chosen because it is the only location on the entire length of the Teton fault where a paleoseismic fault trench has been excavated (Byrd, 1995).

\section{Teton Fault Shallow Seismic Survey Sites}

\section{Taggart Lake}

The Taggart Lake study site is located at the mouth of Avalanche Canyon, where a distinct northstriking Teton fault scarp offsets Taggart Lake basin sediments and the bounding lateral moraines (Figure 2). The basin is bounded to the north, south and east by lateral and terminal moraines, which formed around the toe of the Pinedale-age alpine glacier that flowed eastward from Avalanche Canyon. Inferred sedimentary deposits within the basin include: dense glacial sediment (denoted here as till), Taggart Creek fluvial deposits, lacustrine deposits, colluvium, and

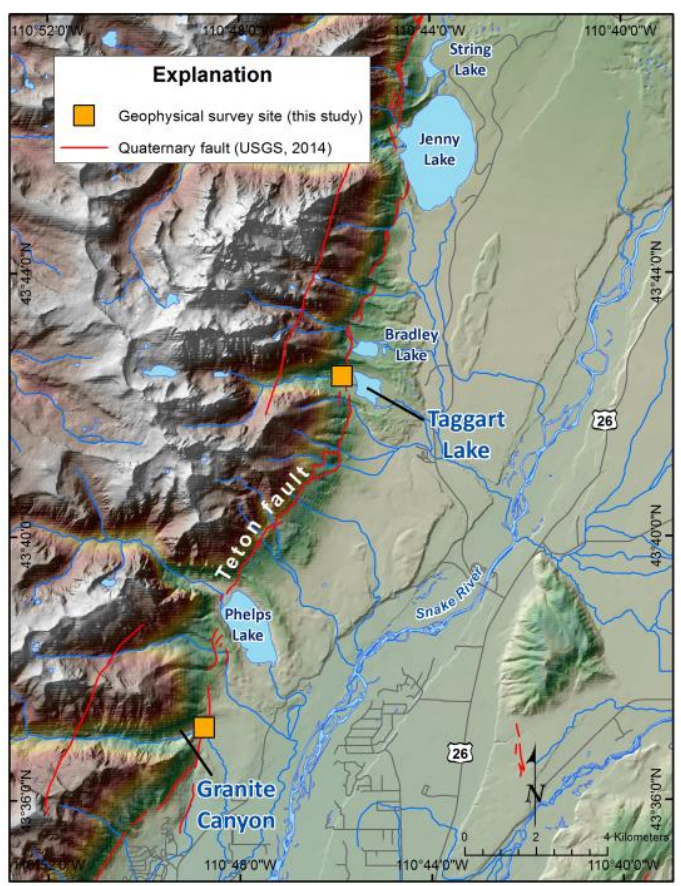

Figure 1. Location map

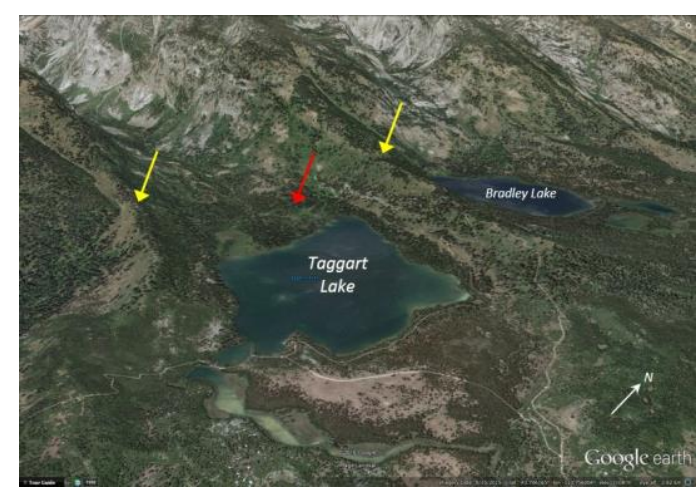

Figure 2. Oblique view of the Taggart Lake basin from Google Earth. The red arrow shows the approximate location of the Taggart Lake seismic survey, which crosses the Teton fault scarp cutting the deglacial surface, and yellow arrows show the Teton fault scarp on bounding lateral moraines.

Cosmogenic ages at Jenny Lake (Figure 1) from Licciardi and Pierce (2008) indicate glacial retreat from the range front 15,000 years ago (ages recalculated using current $10 \mathrm{Be}$ production rate by $\mathrm{J}$. Licciardi, personal communication, 2015).

Within the vicinity of the Taggart basin the organic soil. The glacial deposits are juxtaposed against layered gneiss and migmatite basement rocks (Love et al. 1992) exposed in the footwall. Teton fault has a northerly strike $\left(\sim 6^{\circ}\right)$ and a distinct east-facing scarp. The fault vertically offsets the highest lateral moraines to the north and south of Taggart Lake and 
the basin floor to the west of Taggart Lake. North of Taggart Creek, most of the post-glacial slip appears to have been concentrated on a single fault trace, and to the south of Taggart Creek the fault appears to be segmented and left-stepping as it passes through the large lateral moraine (Figure 3). Small west-dipping antithetic faults are visible near the crests of the lateral moraines to the north and south but are not evident in the Taggart Lake basin floor.

The high lateral moraine between Taggart and Bradley Lakes is vertically offset along a very distinct $27 \mathrm{~m}$ scarp, which indicates a longer record of surface faulting than do the lower scarps in basin sediments or the moraine south of Taggart Lake. The smaller moraine to the south is vertically offset 15.7 $\mathrm{m}$, and the basin floor is vertically offset $12.4 \mathrm{~m}$ (Thackray and Staley, in review).

Preliminary cosmogenic radionuclide CRN exposure ages on moraine boulders from both sides of the scarp (Licciardi et al. 2015), indicate that the high lateral moraine predates the terminal moraines at Taggart Lake by several thousand years.

\section{Granite Creek}

The Granite Creek study site is located at the mouth of Granite Canyon within a wide basin enclosed by lateral and terminal moraines which formed around the toe of a Pinedale-age alpine glacier (Figures 1 and 4). The distinct east facing scarp of the Teton fault vertically offsets sedimentary deposits and the lateral moraines. Post-glacial slip appears to have been concentrated on a single fault trace that strikes $5^{\circ}$ in the southern part of the basin to $0^{\circ}$ in the middle and northern parts of the basin. The Teton fault scarp is most prominent $200 \mathrm{~m}$ to the north of Granite Creek where the synthetic scarp $(13 \mathrm{~m})$ and a smaller antithetic scarp $(\sim 1 \mathrm{~m})$ are mapped (Figure 5). In the southern half of the Granite Creek basin the scarp has been either eroded or transformed into a fault-linescarp due to erosion by Granite Creek, which parallels the scarp for several hundred meters. The only paleoseismic trench exposure of the fault was excavated by Byrd (1995) north of, and adjacent to, Granite Creek (Figure 5).

Inferred sedimentary deposits within the basin include dense glacial sediment (denoted here as till and outwash), Taggart Creek fluvial deposits, colluvium, and organic soil. The glacial deposits are juxtaposed against uplifted Late Archean Rendezvous Metagabbro (Love et al. 1992) exposed in the footwall.

\section{METHODS}

We collected seismic data using a DAQ LinkII seismograph with 24 geophone channels spanning $92 \mathrm{~m}$ and $10 \mathrm{~Hz}$ vertical-component geophones at $4 \mathrm{~m}$ spacing. An aluminum strike plate and $12-\mathrm{lb}$ deadblow hammer were used for active sourcing. This portable system was packed into each site on foot.

At the Taggart and Granite sites, seismic Vp refraction surveys spanning the fault were oriented orthogonal or near-orthogonal to the local fault strike ("dip lines"). IMASW Vs lines intersected the refraction lines and were oriented approximately parallel to local fault strike scarp ("strike lines") (Figure 3 and 5). The Vp refraction dip lines imaged the $2 \mathrm{D}$ cross section of the fault and vertically offset geologic units, and the Vs strike lines are intended to constrain fault dip by imaging the more deeply buried bedrock/alluvial contact that characterizes the Teton fault at depth fault.

At the Taggart Lake site, we collected a single IMASW survey (TLVs-03) on the footwall of the topographic scarp formed by the Teton fault. This survey intersected the Taggart Lake refraction survey (TL-01), collected in 2014 (Thackray et al. 2014), near the former channel 1 location (Figure 3). IMASW survey data for lines TLVs-01 and TLVs-02, collected in 2014 (Thackray et al. 2014) were reprocessed for this effort, providing better resolution of the bedrock / alluvium contact at depth.

At the Granite Creek site we collected two overlapping seismic refraction surveys (GC-01 and GC-02) and one IMASW survey (GCVs-01) (Figure 5 ). The refraction survey lines were oriented $\sim$ N90E and extended from the footwall, over the $13 \mathrm{~m}$ high Teton fault scarp and smaller $(\sim 1 \mathrm{~m})$ antithetic fault scarp, and onto the hanging wall. The center of refraction survey GC-01 was located approximately over the base of the scarp so that half of the survey was located on the footwall (and scarp) and half on the hanging wall. Refraction survey GC-02 was located entirely on the hanging wall. The two refraction surveys had a 6 channel- $20 \mathrm{~m}$ overlap. The single IMASW survey (GCVs-01) was oriented approximately parallel to the immediately local fault strike $\left(\sim 0^{\circ}\right)$ and intersected the refraction survey line on the hanging wall approximately $40 \mathrm{~m}$ east of the scarp. Granite Creek Vp refraction data (GC-01 and GC-02) were processed using Rayfract software. IMASW Vs data were processed using Fugro Consultant's in-house IMASW processing software (O'Connell and Turner 2011). 


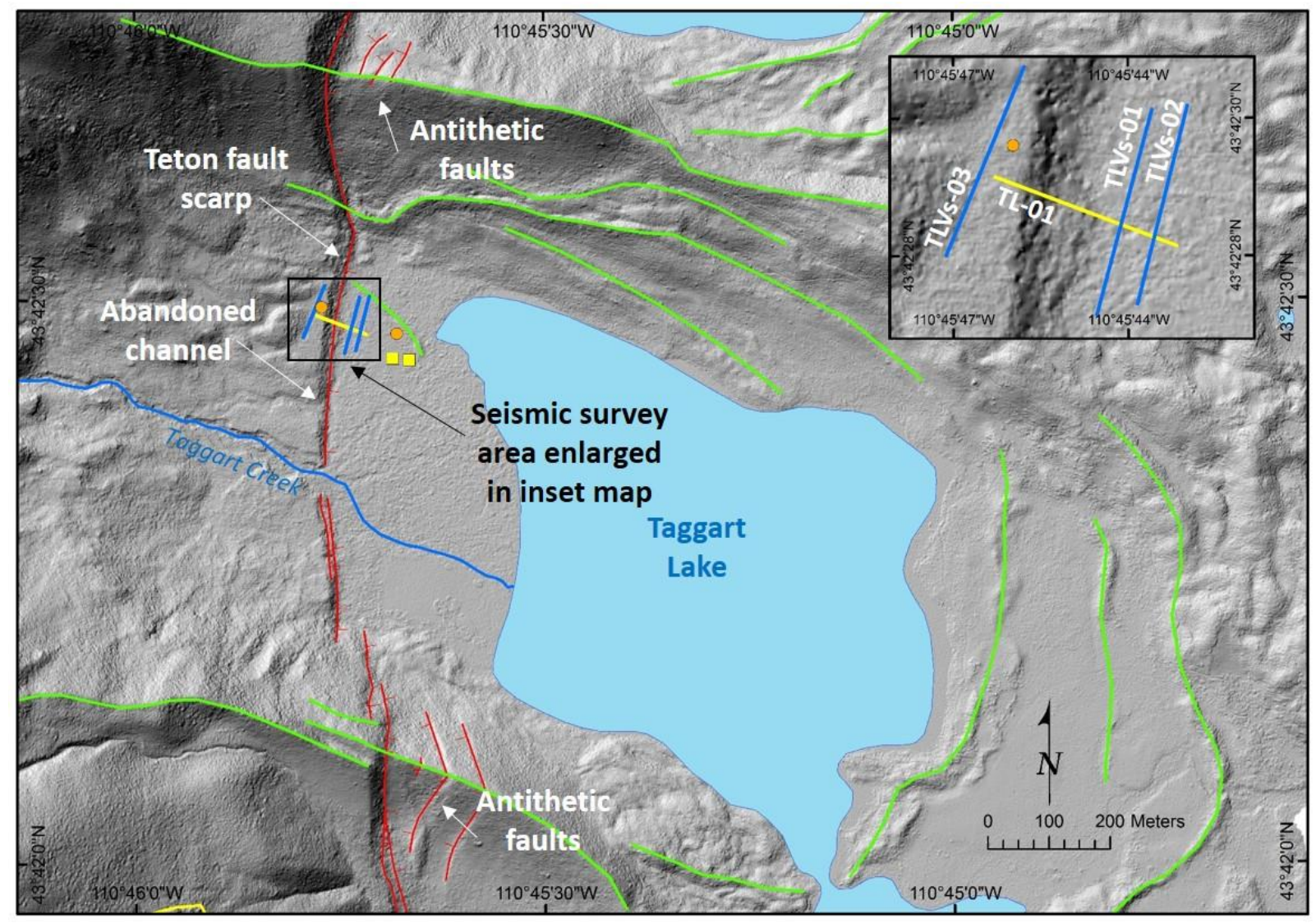

Figure 3. The Taggart Lake study site showing the Teton fault scarp (red lines), moraine crests (green lines), refraction survey (yellow line), IMASW surveys (blue lines), and cosmogenic (orange dot) and radiocarbon (yellow square) sample sites. LiDAR hillshade basemap derived from GTNP (2014) LiDAR.

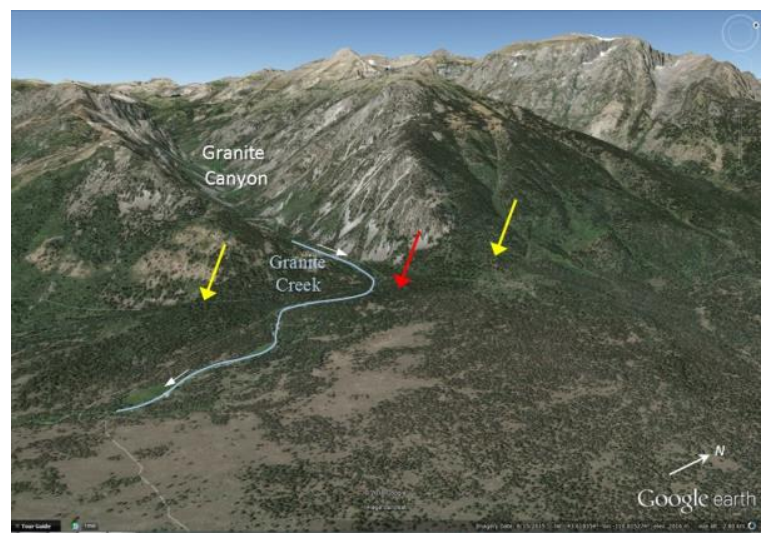

Figure 4. Oblique view of Granite Creek basin from Google Earth. Yellow arrows show the Teton fault scarp on bounding lateral moraine crests. Red arrow shows the approximate location of Granite Creek seismic survey and Byrd (1995) and Byrd et al. (1994) paleoseismic site.

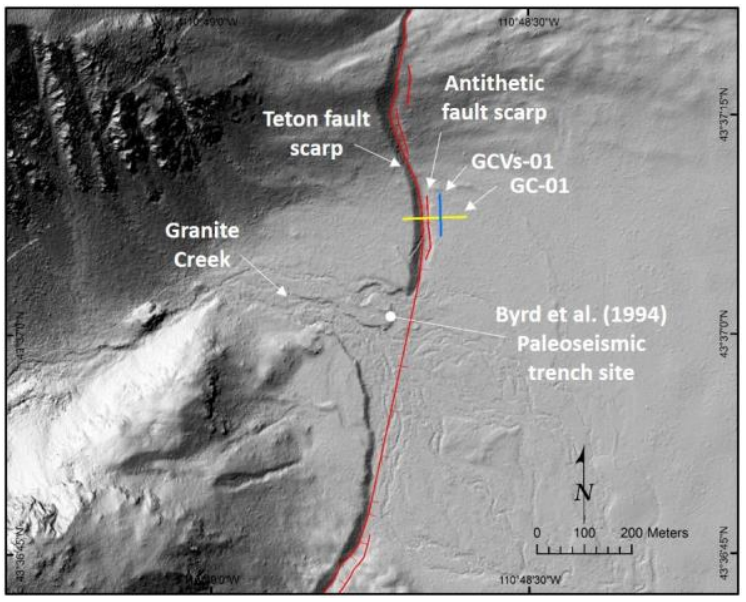

Figure 5. The Granite Creek study site showing the Teton fault scarp (red lines), refraction survey (yellow line), IMASW survey (blue line), and the location of the Byrd (1995) and Byrd et al. (1994) paleoseismic study site are shown. LiDAR hillshade basemap derived from GTNP (2014) LiDAR. 


\section{$\uparrow \quad$ RESULTS}

Shallow 2D P-wave refraction profiles and IMASW Vs vs. Depth plots from both the Taggart Lake and Granite Creek sites imaged subsurface velocity structure that reveal down-to-the east vertical offset across the Teton fault and provide a basis for assessing the fault in the shallow subsurface. The subsurface is not constrained with borehole data or any empirical measurements at these locations, so interpretations are based on geologic and geomorphic context and correlation charts for relating $\mathrm{Vp}$ and $\mathrm{Vs}$ to material (Table 1.).

In this report we present IMASW Vs-depth plots for IMASW surveys TLVs-01, TLVs-02, TLVs03, and GCVs-01 (Figure 6). Each plot is presented in 1 of 3 different formats. The reason for the variability in appearance is because different processing scripts were applied to account for unique site conditions between the different surveys, and because the data were plotted at different times throughout a software update phase. Though the appearance may be variable from figure to figure, the data results are consistent. Plots of these data in subsequent presentations will apply a consistent and standardized format.

\begin{tabular}{|l|l|l|}
\hline $\begin{array}{c}\text { Type of } \\
\text { Material }\end{array}$ & $\begin{array}{c}\text { P wave } \\
\text { velocity } \\
(\mathbf{V p})(\mathbf{m} / \mathbf{s})\end{array}$ & $\begin{array}{c}\text { S wave } \\
\text { velocity } \\
\mathbf{( V s})(\mathbf{m} / \mathbf{s})\end{array}$ \\
\hline $\begin{array}{l}\text { Scree, Vegetal } \\
\text { soil }\end{array}$ & $300-700$ & $100-300$ \\
\hline Dry sands & $400-1200$ & $100-500$ \\
\hline Wet sands & $1500-2000$ & $400-600$ \\
\hline Granite & $4500-6000$ & $2500-3300$ \\
\hline Gneiss & $4400-5200$ & $2700-3200$ \\
\hline
\end{tabular}

Table 1. Correlated $\mathrm{P}$-wave and $\mathrm{S}$-wave velocities for generalized material types (Bourbie et al. 1987).

\section{Taggart Lake}

At Taggart Lake a total of 3 IMASW surveys have been collected (Figure 3). One IMASW survey (TLVs-03) was acquired in 2015 on the Teton fault footwall, and two IMASW surveys (TLVs-01 and TLVs-02) were collected in 2014 on the fault hanging wall (Thackray et al. 2014). As part of this study, the 2014 survey data has been reprocessed and re- interpreted with TLVs-03 to estimate the depth to crystalline bedrock and fault characteristics in the shallow subsurface.

Each of the Vs-depth plots (TLVs-01, TLVs02, and TLVs-03) (Figure 6) show distinct Vs inflections that are interpreted to be transitions between geologic units and material types (i.e., alluvium, till, crystalline bedrock). At Taggart Lake, we interpret the shallow, slow $(\mathrm{Vp}<1500 \mathrm{~m} / \mathrm{s} / \mathrm{Vs} \leq$ $500 \mathrm{~m} / \mathrm{s}$ ) velocity zone to be a mantle of unconsolidated post-glacial alluvial and organic material overlying glacial outwash and till (Vs >500 $\mathrm{m} / \mathrm{s}$ and $<\sim 2000 \mathrm{~m} / \mathrm{s}$, and $\mathrm{Vs}>\sim 2000 \mathrm{~m} / \mathrm{s}$ to be crystalline bedrock.

IMASW surveys TLVs-01 and TLVs-02 (Figure 6) show a pronounced increase in Vs at $\sim 220$ $\mathrm{m}$ depth $(+/-35 \mathrm{~m})$, which is interpreted to be associated with the bedrock/alluvium contact. The uncertainty associated with the depth of the Vs increase is high $(>\% 20)$ because the depth more than twice the length of the survey length $(92 \mathrm{~m})$. At IMASW survey TLVs-03 (Figure 6) the bedrock alluvial contact is estimated to be at a depth of $70-80$ m depth.

\section{Granite Creek}

At Granite Creek the two overlapping seismic refraction surveys, GC-01 and GC-02, spanned the Teton fault scarp north of the Byrd (1995) trench site and imaged the fault zone and both the hanging wall and footwall to depths of approximately 20-30 m (Figures 5). The refraction profile shows a layered velocity structure that is vertically offset across the Teton fault (Figure 7).

The measured vertical offset of velocity contours (i.e., $\sim 1000 \mathrm{~m} / \mathrm{s}$ ) is measured to be approximately $13 \mathrm{~m}$, which is equivalent to the measured vertical height of the topographic scarp at this location $(13 \mathrm{~m})$, inferred by Thackray and Staley (in review) to have developed since deglaciation, ca. 15,000 years ago. The single IMASW survey (GCVs01 ) intersected the seismic refraction profile at a point $\sim 40 \mathrm{~m}$ east of the base of the scarp. The Vs vs. Depth plot for GCVs-01 (Figure 6) shows a low velocity zone $(<500 \mathrm{~m} / \mathrm{s})$ at depths shallower than $7 \mathrm{~m}$. Between $7 \mathrm{~m}$ and $\sim 11 \mathrm{~m} \mathrm{Vs}$ increases to $\sim 800 \mathrm{~m} / \mathrm{s}$ which is maintained to a depth $>40 \mathrm{~m}$, which was our maximum depth resolution at this site. 
A)
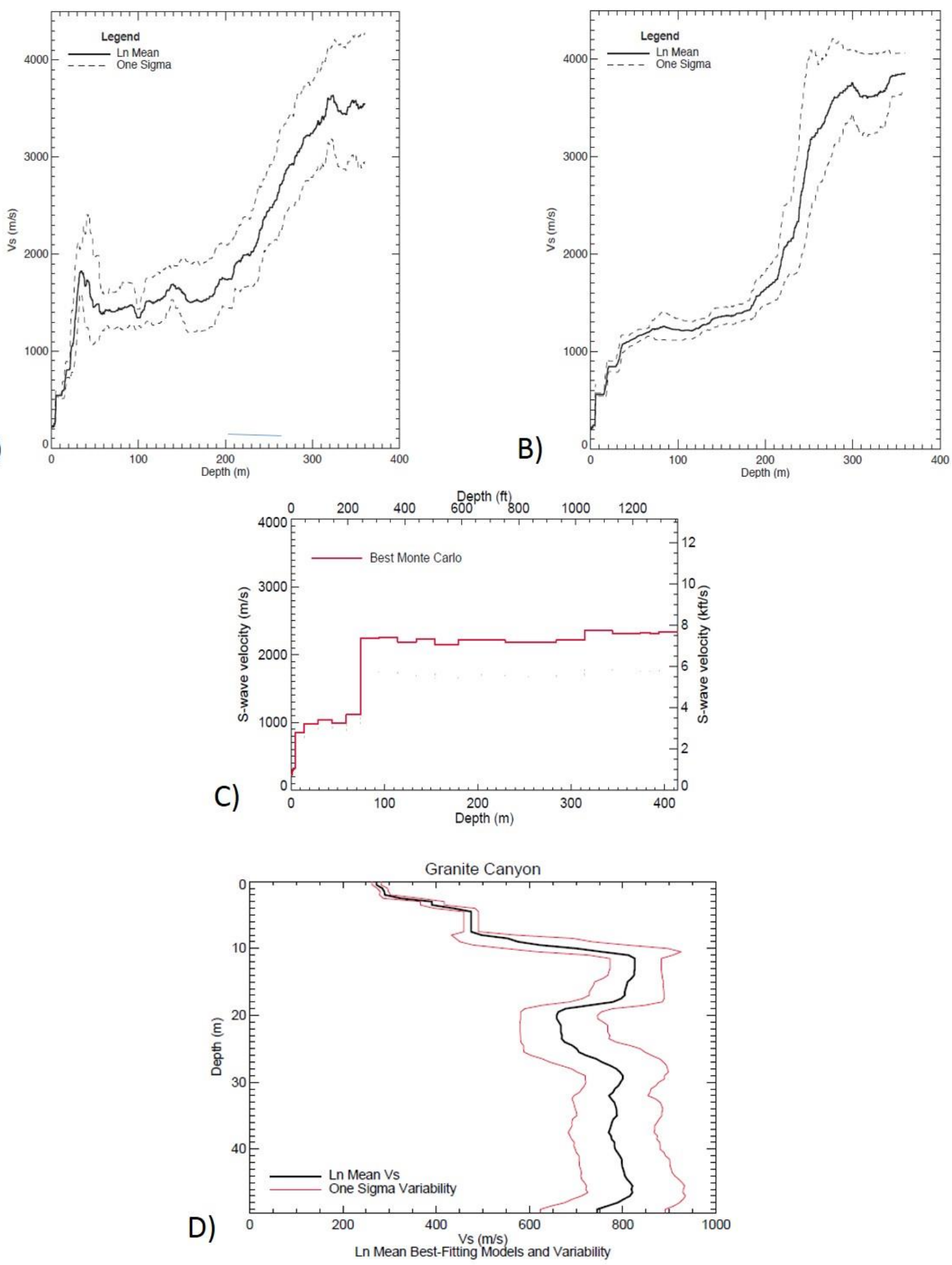

Figure 6. IMASW Depth $v s$. Vs profiles for Taggart Lake IMASW surveys (A) TLVs-01, (B) TLVs-02, and (C) TLVs-03, and Granite Creek IMASW survey (D) GCVs-01. See text for explanation of contrasting profile styles, and note that the axes are reversed in D. See Table 1 for relative velocities in contrasting materials. 


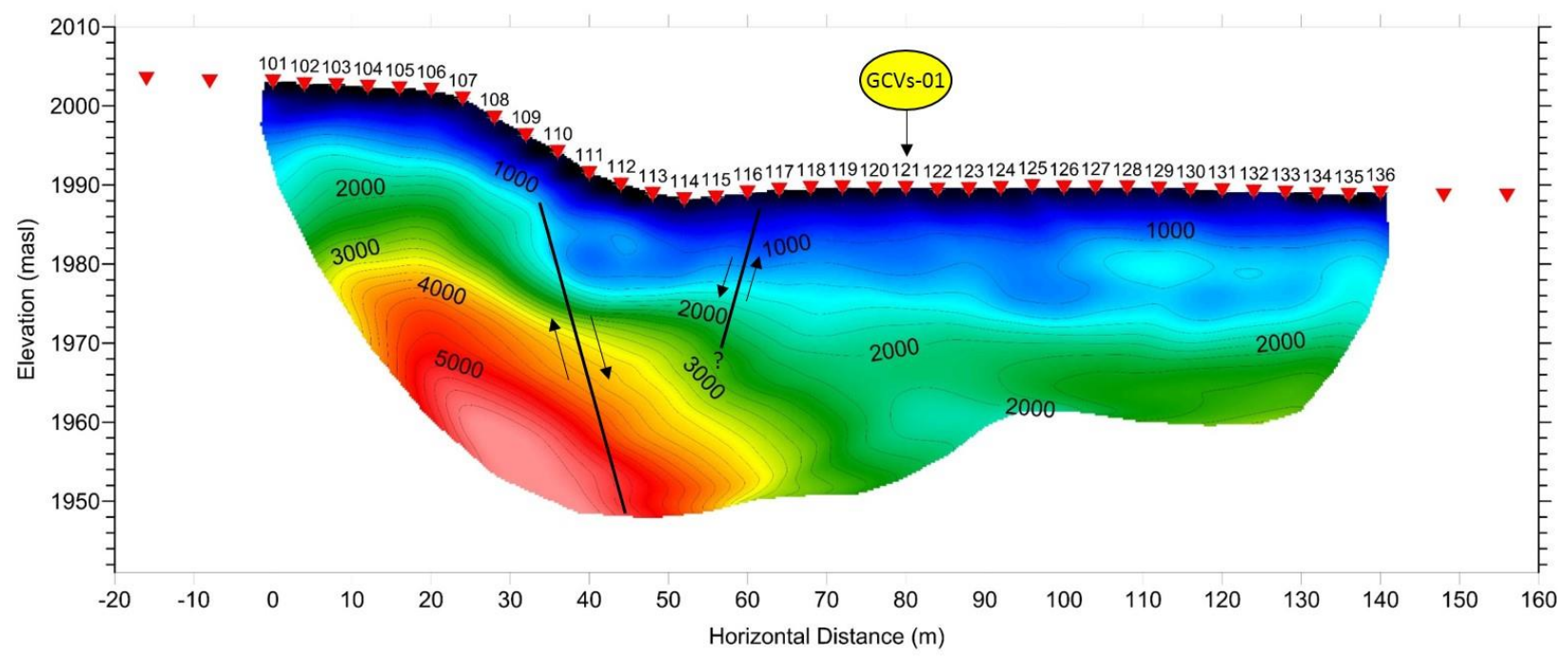

Source Location

50010001500200025003000350040004500500055006000

P-Wave Velocity $(\mathrm{m} / \mathrm{s})$

Figure 7. Granite Creek 2D P-wave refraction profile with fault interpretations. The intersection point of IMASW survey GCVs-01 is indicated.

At Granite Creek, we interpret the shallow, slow $(\mathrm{Vp}<1500 \mathrm{~m} / \mathrm{s} / \mathrm{Vs} \leq 500 \mathrm{~m} / \mathrm{s})$ velocity zone to be a mantle of unconsolidated post-glacial alluvium and organic cover overlying glacial outwash and till (Vs $>500 \mathrm{~m} / \mathrm{s}$ ). A Vs indicative of crystalline bedrock $(>2000 \mathrm{~m} / \mathrm{s}$ ) was not observed within the resolution of the data at this site.

Figure 8 shows a conceptual structural schematic of the subsurface at the Taggart Lake study site. The Teton fault zone is shown as a wedge to convey uncertainty in location with depth. The wedge is defined by planes that are projected between the location of the Teton fault at the ground surface, estimated from the 2D P-wave tomography and surficial mapping (Thackray et al. 2014), and the 1sigma uncertainty zones associated with the TLVs-01 and TLVs-02 depth picks. The estimated depth to top of bedrock for TLVs-01 and TLVs-02 suggest the Teton fault dips at least $70^{\circ}$, to a depth of $\sim 220 \mathrm{~m}$. This dip estimate is steeper than the $\sim 63^{\circ}$ dip previously estimated in Thackray et al. (2014, Figure 12). This revised estimate is viewed as preliminary and subject to change based on additional information and model refinement.

\section{$\uparrow \quad$ CONCLUSIONS}

Shallow seismic surveys at Taggart Lake and Granite Creek spanned the Teton fault and imaged the fault zone in the subsurface with 2D P-wave refraction surveys and IMASW Vs surveys. These surveys provide information that is useful for evaluating the shallow subsurface fault geometry and for estimating the total vertical faulted offsets since deglaciation. However, this study did not include empirical subsurface data (such as a borehole) and, as such, the geophysical data provide best available estimates.

At Granite Creek, 12-13 m of vertical offset across the Teton fault is measured from the interpreted buried deglacial surface from 2D P-wave seismic profiles (Figure 6). This estimate is similar to the measured height of the topographic scarp at the same location $(13 \mathrm{~m})$, and therefore suggests that the topographic scarp in some locations can provide a reasonable estimate for post-glacial faulted offsets. Our analysis at Taggart Lake in 2014 provided similar findings (Thackray et al. 2014). The subsurface fault offset is estimated at $13 \mathrm{~m}$, which is similar to the 12.4 $\mathrm{m}$ vertical scarp height at the site from Thackray and Staley (in review). 


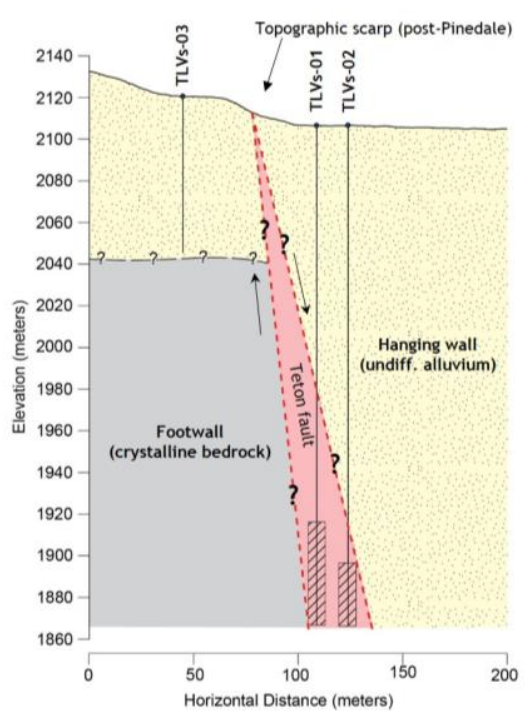

Figure 8. Conceptual structural schematic of the Teton fault at depth in Taggart Lake basin based on IMASW surveys TLVs-01, TLVs-02, and TLVs-03. The Teton fault is shown as a wedge to depict increasing uncertainty of geometry and location with depth. Hachured boxes at base of IMASW survey profile line represent 1 -sigma uncertainty zone for estimated depth to top of rock.

The measured depth to crystalline bedrock on the Teton fault footwall at Taggart Lake remains uncertain due to a lack of boreholes or other direct observations. However, IMASW surveys (TLVs-01, TLVs-02, and TLVs-03) provide reasonable estimated for contact depth. TLVs-03 (Figure 6) encountered what we interpret to be the top of crystalline bedrock at a depth of $\sim 70-80 \mathrm{~m}$ (i.e., Teton fault footwall) based on an abrupt increase from $\sim \mathrm{Vs} 1000 \mathrm{~m} / \mathrm{s}$ to $\sim \mathrm{Vs}$ $2100 \mathrm{~m} / \mathrm{s}$ (Figure 6). The nature of the interpreted bedrock contact in the footwall survey (TLVs-03) is unknown, but because of its location on the footwall in a previously glaciated valley this contact is interpreted to be erosional. In TLVs-01 and TLVs-02 the bedrock/alluvial contact is interpreted to be faulted (Figure 8) at a depth of $\sim 220 \mathrm{~m} \mathrm{(+/-} 35 \mathrm{~m}$ ) (Figure 6), and we estimate fault dip of at least $70^{\circ}$ to a depth of $220 \mathrm{~m}$.

\section{$\uparrow \quad$ ACKNOWLEDGEMENTS}

This research was funded by the University of Wyoming - National Park Service Research Station and by in-kind contributions from Fugro Consultants, Inc. and Idaho State University. David Rodgers, Amie Staley, and Nick Patton (ISU) assisted with data collection, and Glen Adams, Dan O'Connell, Dean Ostenaa, and Jamey Turner (FCL) assisted with project design and geophysical data analysis.

\section{Literature Cited}

Bourbie, T., O. Coussy, Zinszner. 1987. Acoustics of Porous Media, Gulf Publishing Company.

Byrd, J.O.D. 1995. Neotectonics of the Teton fault, Wyoming [Ph.D. thesis]: University of Utah, Salt Lake City, UT. 213 pp.

Byrd, J.O., R.B. Smith, and J.W. Geissman. 1994. The Teton fault, Wyoming: Topographic signature, neotectonics, and mechanisms of deformation, Journal of Geophysical Research, 99:20095-20122.

EarthScope Intermountain Seismic Belt LiDAR Project (EarthScope). 2008. EarthScope Intermountain Seismic Belt LiDAR Project: http://opentopo.sdsc.edu, 10.5069/G9VD6WCS (Accessed July 2014).

Licciardi, J.M., and K.L. Pierce. 2008. Cosmogenic exposure-age chronologies of Pinedale and Bull Lake glaciations in greater Yellowstone and the Teton Range, USA. Quaternary Science Reviews. 27:814-831. doi:10.1016/j.quascirev.12.005.

Licciardi, J.M., K.L. Pierce, G.D. Thackray, R.C. Finkel, and S.R.H. Zimmerman. 2015. Cosmogenic 10Be chronologies of moraines and glacially scoured bedrock in the Teton Range, with implications for paleoclimatic events and tectonic activity. Abstract PP51E02 presented at 2015 Fall Meeting, AGU, San Francisco, Calif., 14-18 Dec.

Love, J., J. Reed, and A.C. Christiansen. 1992. Geologic Map of Grand Teton National Park, Teton County, WY, U.S.G.S. Miscellaneous Investigations Series, Map I-2031.

O'Connell, D., and J.P. Turner. 2011. Interferometric Multichannel Analysis of Surface Waves (IMASW), Bulletin Seismological Society of America. 101:2122-2141.

Grand Teton National Park (GTNP). 2014. unpublished LiDAR dataset. Teton National Park, Wyoming.

Thackray, G.D., and A.E. Staley (in revision). Fault scarp offsets document extensive MIS $4 / 3$ glaciation in western interior North America, Teton Range, Wyoming, USA. in revision following review, Geosphere.

Thackray, G.D., M. Zellman, J. Altekruse, B. Protti, and H. Colandrea. 2014. Shallow seismic investigation of the Teton fault. University of Wyoming-National Park Service Research Center Annual Reports 37:2-10. http://repository.uwyo.edu/uwnpsrc_reports/ 